\title{
Spatiotemporal Patterns in Nest Box Occupancy by Tree Swallows Across North America
}

\section{Tendance spatiotemporelle de l'occupation de nichoirs par l'Hirondelle bicolore en Amérique du Nord}

\author{
$\underline{\text { Dave Shutler }}^{1}, \underline{\text { David J.T. Hussell }}^{2}, \underline{\text { D. R. Norris }}^{3}, \underline{\text { David W. Winkler }}^{4}, \underline{\text { Raleigh J.Robertson }}^{5}, \underline{\text { Frances Bonier }}^{5}$, \\ Wallace B. Rendell $^{6}$, Marc Bélisle ${ }^{7}$, Robert G. Clark ${ }^{8}$, Russell D. Dawson ${ }^{9}$, Nathaniel T. Wheelwright ${ }^{10}$,

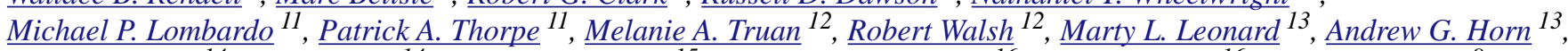 \\ $\underline{\text { Carol M. Vleck }}^{14}{ }^{\text {David Vleck }}{ }^{14}, \underline{\text { Alexandra P. Rose }}^{15}, \underline{\text { Linda A. Whittingham }}^{16}, \underline{\text { Peter O. Dunn }}^{16}, \underline{\text { Keith A. Hobson }}^{8}$, and \\ Mark T. Stanback
}

\begin{abstract}
Data from the North American Breeding Bird Survey (BBS) suggest that populations of aerial insectivorous birds are declining, particularly in northeastern regions of the continent, and particularly since the mid-1980s. Species that use nest boxes, such as Tree Swallows (Tachycineta bicolor), may provide researchers with large data sets that better reveal finer-scale geographical patterns in population trends. We analyzed trends in occupancy rates for ca. 40,000 Tree Swallow nest-box-years from 16 sites across North America. The earliest site has been studied intensively since 1969 and the latest site since 2004. Nest box occupancy rates declined significantly at five of six $(83 \%)$ sites east of $-78^{\circ} \mathrm{W}$ longitude, whereas occupancy rates increased significantly at four of ten sites $(40 \%)$ west of $-78^{\circ} \mathrm{W}$ longitude. Decreasing box occupancy trends from the northeast were broadly consistent with aspects of a previous analysis of BBS data for Tree Swallows, but our finding of instances of increases in other parts of the continent are novel. Several questions remain, particularly with respect to causes of these broadscale geographic changes in population densities of Tree Swallows. The broad geographic patterns are consistent with a hypothesis of widespread changes in climate on wintering, migratory, or breeding areas that in turn may differentially affect populations of aerial insects, but other explanations are possible. It is also unclear whether these changes in occupancy rates reflect an increase or decrease in overall populations of Tree Swallows. Regardless, important conservation steps will be to unravel causes of changing populations of aerial insectivores in North America.
\end{abstract}

RÉSUMÉ. Les données provenant du Relevé des oiseaux nicheurs (BBS) de l'Amérique du Nord semblent indiquer que les populations d'insectivores aériens sont en déclin, particulièrement dans les régions du nord-est du continent et depuis le milieu des années 1980. Grâce aux espèces qui utilisent les nichoirs, comme l'Hirondelle bicolore (Tachycineta bicolor), les chercheurs ont accès à une grande quantité de données qui révèlent davantage les tendances des populations à l'échelle fine. Nous avons analysé la tendance du taux d'occupation par l'Hirondelle bicolore à partir de 40000 nichoirs-années provenant de 16 sites répartis en Amérique du Nord. Le site le plus ancien est suivi intensivement depuis 1969 et le plus récent, depuis 2004. Le taux d'occupation des nichoirs a diminué significativement dans 5 des 6 sites $(83 \%)$ situés à l'est du $78^{\circ}$ de longitude ouest, tandis qu'il a augmenté significativement dans 4 des 10 sites (40\%) à l'ouest du $78^{\circ}$ de longitude ouest. La tendance à la baisse de l'occupation observée dans le nord-est concorde dans les grandes lignes avec les résultats d'une analyse antérieure des données du BBS pour cette espèce, mais les hausses que nous avons observées dans d'autres régions de l'Amérique du Nord s'avèrent nouvelles. Plusieurs interrogations demeurent, notamment en ce qui a trait aux causes de ces changements dans la densité des populations d'Hirondelles bicolores à grande échelle. Ces vastes tendances géographiques concordent avec l'hypothèse de changements climatiques généralisés qui toucheraient les aires d'hivernage, de migration ou de nidification, lesquels pourraient affecter différemment les populations d'insectes aériens, mais d'autres explications sont aussi possibles. En outre, nous ne savons pas si ces changements du taux d'occupation reflètent une hausse ou une baisse dans l'ensemble des populations d'Hirondelles bicolores. Néanmoins, pour assurer leur conservation, il sera important d'élucider les causes des changements de populations chez les insectivores aériens en Amérique du Nord.

Key Words: avian aerial insectivore, migrant, nest boxes, North American Breeding Bird Survey, population trends, Tree Swallow

${ }^{1}$ Acadia University, Canada, ${ }^{2}$ Ontario Ministry of Natural Resources, Canada, ${ }^{3}$ University of Guelph, ${ }^{4}$ Cornell University, U.S.A., ${ }^{5}$ Queen's University, Canada, ${ }^{6}$ Loyalist College, Canada, ${ }^{7}$ Université de Sherbrooke, Canada, ${ }^{8}$ Environment Canada, ${ }^{9}$ University of Northern British Columbia, Canada, ${ }^{10}$ Bowdoin College, U.S.A., ${ }^{11}$ Grand Valley State University, U.S. A., ${ }^{12}$ University of California, Davis, U.S.A., ${ }^{13}$ Dalhousie University, Canada, ${ }^{14}$ Iowa State University, U.S.A., ${ }^{15}$ University of Wyoming, U.S. A., ${ }^{16}$ University of Wisconsin-Milwaukee, U.S.A, ${ }^{17}$ Davidson College, U. S.A.
Sponsored by the Society of Canadian Ornithologists and Bird Studies Canada Parrainée par la Société des ornithologistes du Canada et Etudes d'oiseaux Canada

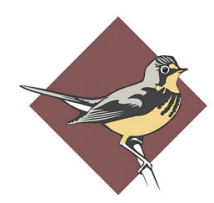
BIRD STUDIES CANADA 


\section{INTRODUCTION}

Previous studies have suggested that populations of North American aerial avian insectivores are decreasing (Robbins et al. 1989, Böhning-Gaese et al. 1993, Askins 1995). Most recently, based on North American Breeding Bird Survey (BBS) data from between 1966 and 2006 and including most BBS routes for Canada and the United States (excluding Alaska, Yukon, and states or provinces with 15 or fewer BBS routes), Nebel et al. (2011) concluded that Tree Swallow (Tachycineta bicolor) populations were among the species of decreasing aerial insectivores, especially in northeastern North America. BBS data, such as those analyzed by Nebel et al. (2011), are collected along roads, and are most concentrated near areas of high human population density (see Sauer et al. 2011 for details on spatiotemporal coverage). In many parts of their range, distribution of Tree Swallows is patchy, and if BBS routes do not adequately sample these patches, swallow population trends may not be clearly discerned.

Tree Swallows readily take advantage of nest boxes, providing several research advantages. As a consequence, box occupancy rates of Tree Swallows are intensely monitored by numerous researchers across North America, often for extended intervals (Jones 2003, Golondrinas 2011, Winkler et al. 2011). There is a tradeoff between nest boxfocused monitoring on sites versus the spatial and temporal breadth of coverage provided by BBS data, and it is an open question as to which source of information better reflects actual trends at broader geographical scales. Here, we examine nest box occupancy rates of Tree Swallows to evaluate whether these data suggest spatiotemporal patterns of population changes. We also evaluate whether these data produce conclusions similar to those of Nebel et al. (2011). Similar results from both sources of data would add credence to patterns reported by Nebel et al. (2011).

\section{METHODS}

We compiled occupancy data from 16 Tree Swallow sites spread across North America (Fig. 1). Our sites spanned 4091 $\mathrm{km}$ from west to east and $2035 \mathrm{~km}$ from south to north (Fig. 1). At most sites, nest boxes for Tree Swallows were erected $\sim 1.5 \mathrm{~m}$ above ground and $\geq 20 \mathrm{~m}$ apart (as suggested by Muldal et al. 1985), generally close to aquatic habitats from which adult stages of aquatic insects emerge, providing a key food source for swallows (Hussell and Quinney 1987). Boxes were usually visited every 1 to $3 \mathrm{~d}$ (up to $7 \mathrm{~d}$ ) at the start of the breeding season to record clutch initiation and completion, and visited less frequently during incubation and nestling stages. First eggs are typically laid from early April in the south to late May in the north, with last clutch initiations in mid-July (Shutler et al. 2006, Winkler et al. 2011). In this study, a box was considered occupied if it contained a nest with at least one egg. Tree Swallows are rarely doublebrooded north of $42^{\circ} \mathrm{N}$ (Hussell 1983, 2003a); this occurs occasionally in California and the southern U.S. (Wasserman 2003, Monroe et al. 2008, Stanback personal observation).

The Long Point-Ontario site has had the longest continuous monitoring (since 1969), whereas the youngest site was established in Québec in 2004 (Table 1). The New Brunswick site, originally established in 1934, also had data from 1947 (occupancy $73.3 \%$ of 30 boxes) and 1948 (occupancy 62.0\% of 50 boxes) (Paynter 1954). Because of the large gap in records before consistent monitoring, we excluded these latter data from analysis, although they do suggest sub-maximal occupancy rates in the past (Fig. 1).

Depending on the site, Ash-throated Flycatchers (Myiarchus cinerascens), Great Crested Flycatchers (Myiarchus crinitus), Oak Titmice (Baeolophus inornatus), White-breasted Nuthatches (Sitta carolinensis), Black-capped Chickadees (Poecile atricapillus), Boreal Chickadees (Poecile hudsonicus), House Sparrows (Passer domesticus), House Wrens (Troglodytes aedon), bluebirds (Sialia sialis, S. mexicana, S. currucoides), and Violet-green Swallows (Tachycineta thalassina) occupied a minority of boxes (typically $<10 \%$ ), and thus were unlikely to significantly alter Tree Swallow occupancy rates. Moreover, on the only site (California) where these species collectively had increasing occupancy rates, so did Tree Swallows. Hence, for simplicity, our Tree Swallow occupancy rates were based on the total number of boxes available. In our analyses, we pooled subsites that in some cases differed significantly in quality, which varies with insect densities, rates of predation, and microclimate. Differences in quality of sites at this smaller scale can affect occupancy rates (Hussell 2012). However, some subsites had fewer than 15 boxes, making analyses of trend estimates of occupancy rates within subsites potentially tenuous. In any case, we were mostly concerned with broader geographic patterns.

We used SAS 9.2 (Statistical Analysis Systems, Cary, North Carolina) and R (2.13.0, R Core Development Team 2006) for analyses. Within each site, we first computed logistic regression slopes (reported $\pm \mathrm{SE}$ ) where occupied boxes and number of boxes available were simultaneous response variables and year was the explanatory variable (Crawley 2005). Error distributions were set as quasi-binomial. For sites with $>10 \mathrm{yr}$ of data, we also included $\mathrm{yr}^{2}$ and $\mathrm{yr}^{3}$ as explanatory variables, removing sequentially non-significant associations to produce final models (Crawley 2005). The first year of data was retained in scatterplots (Fig. 1), but excluded in analyses for most sites because occupancy rates are typically low until the second year (e.g., Chapman 1935, Shutler and Clark 2003). Including first-year data would thus positively bias yearoccupancy correlations. The Nova Scotia-1, New Brunswick, Ontario-Long Point, California, and Alaska sites had been in operation before occupancy data were collected, so the first year of data was not excluded for those computations. The Nova Scotia-1 and -2 sites are very close geographically (Fig. 
Fig. 1. Location and occupancy rates over time of Tree Swallow sites. Scatterplots associated with open circles over sites have negative trends (Table 1); closed circles indicate increasing trends.

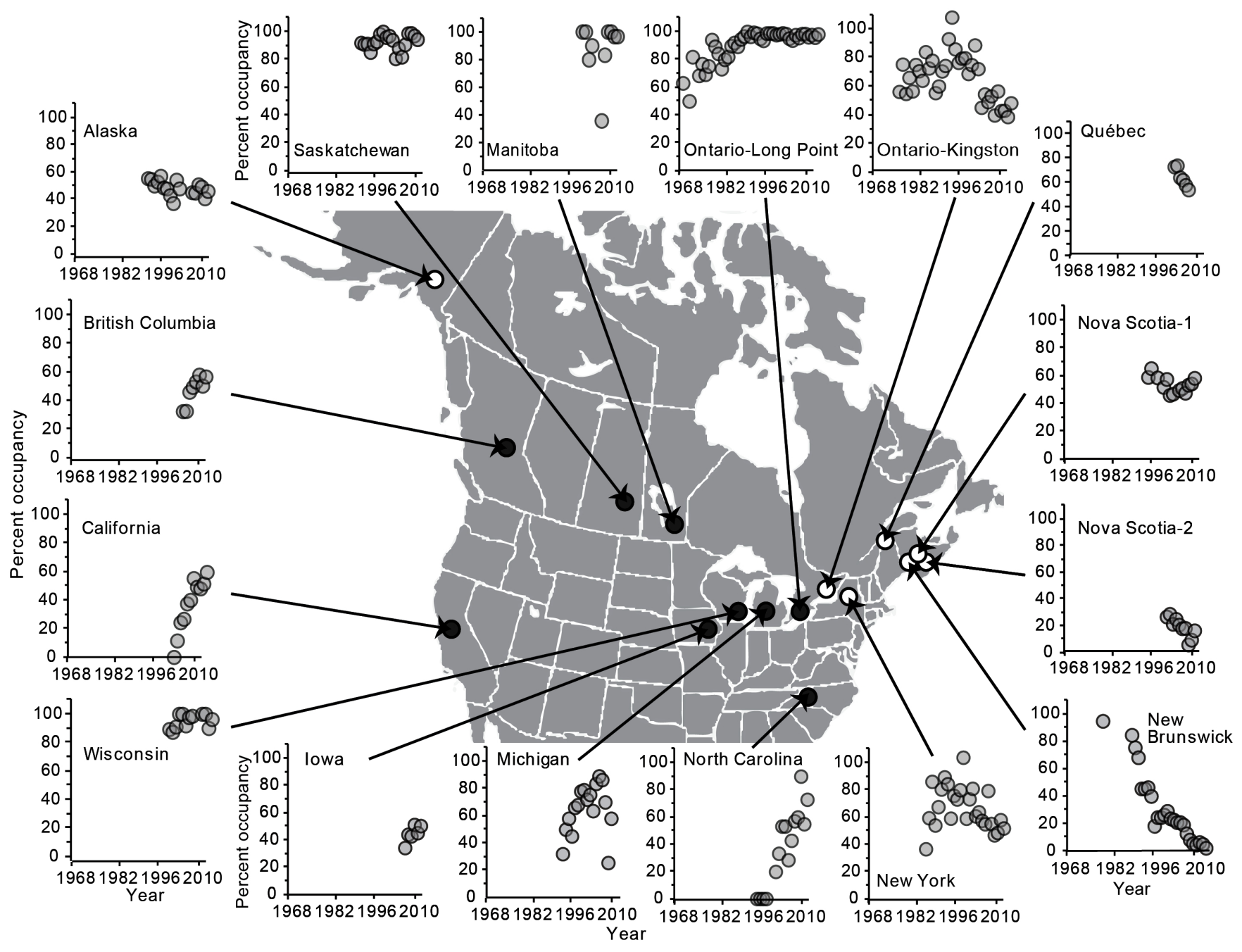

1), but the latter had boxes with both small (for Tree Swallows) and large (for other passerines) openings; thus occupancy rates were not directly comparable and data from these two sites were treated independently. The number of boxes on many sites fluctuated for various reasons (e.g., new boxes were added, boxes were destroyed), and this could similarly have affected initial occupancy rates (analyses using total number of nests provided qualitatively similar results). For simplicity, we assumed that once sites were initiated, new subsites adjacent to these were not subject to initial low occupancy (Shutler unpublished analysis).

Prior to analysis, we examined occupancy data for each site and identified years with unusually low occupancy rates that were deemed to have been driven by preceding years of unusually severe predation events. We ran analyses twice within these sites, both including and excluding data subsequent to years with high predation rates. Additionally, we identified years where occupancy rates were greater than $100 \%$ because new females had built second nests in boxes after earlier nest attempts by different females; in these instances, we reset occupancy rates for those years to $100 \%$ because these events were not recorded consistently at all sites.

Using slopes from logistic regressions for each site as our response variable, we used a GLM with distance north (hereafter, North) from the center of our study area $\left(44.7^{\circ} \mathrm{N}\right.$ 
Table 1. Site details (Fig. 1) and results of logistic regressions with number of occupied boxes and number of boxes as response variables, year as explanatory variable, and error distributions set as quasi-binomial. Sites are arranged by longitude. $\beta$ is the slope, and SE $\beta$ is the standard error of the slope estimate. Significant slopes in bold.

\begin{tabular}{|c|c|c|c|c|c|c|c|c|c|}
\hline Site name & Site name, researchers & $\begin{array}{l}\text { Latitude } \\
\mathrm{N}\end{array}$ & $\begin{array}{c}\text { Longitude } \\
\text { W }\end{array}$ & $\begin{array}{l}\text { Box- } \\
\text { years }\end{array}$ & $\begin{array}{l}\text { First } \\
\text { year }\end{array}$ & $\beta$ & SE $\beta$ & $t$ & $P$ \\
\hline Nova Scotia-1 & Gaspereau, Leonard/Horn & 45.0 & -64.2 & 1529 & 1994 & -0.015 & 0.012 & -1.3 & 0.21 \\
\hline Nova Scotia-2 & Wolfville, Shutler & 45.0 & -64.3 & 1786 & 2001 & -0.107 & 0.025 & -4.3 & 0.003 \\
\hline New Brunswick & Kent Island, Wheelwright & 44.4 & -66.5 & 2190 & 1987 & -0.186 & 0.019 & -9.9 & $\begin{aligned}< & 0.00- \\
& 01\end{aligned}$ \\
\hline Québec & Eastern Townships, Bélisle & 45.6 & -72.6 & 2800 & 2004 & -0.181 & 0.024 & -7.4 & 0.002 \\
\hline Ontario-Kingston & $\begin{array}{l}\text { Lake Opinicon Robertson/ } \\
\text { Bonier/Rendell }\end{array}$ & 44.6 & -76.3 & 5259 & 1975 & -0.036 & 0.012 & -3.0 & 0.005 \\
\hline New York & Ithaca, Winkler & 42.5 & -76.5 & 6137 & 1986 & -0.063 & 0.017 & -3.7 & 0.001 \\
\hline Ontario-Long Point & Long Point, Hussell/Norris & 42.5 & -80.0 & 6563 & 1969 & 0.098 & 0.011 & 8.8 & $\begin{aligned}< & 0.00- \\
& 01\end{aligned}$ \\
\hline North Carolina & Davidson, Stanback & 35.5 & -80.9 & 394 & 1996 & 0.218 & 0.058 & 3.8 & 0.004 \\
\hline Michigan & Allendale, Lombardo/Thorpe & 43.0 & -86.0 & 1850 & 1993 & 0.044 & 0.041 & 1.1 & 0.30 \\
\hline Wisconsin & Saukville, Whittingham/Dunn & 43.0 & -88.0 & 1042 & 1998 & 0.097 & 0.082 & 1.2 & 0.27 \\
\hline Iowa & Ames, Vleck/Vleck & 42.0 & -94.0 & 1269 & 2004 & 0.083 & 0.040 & 2.1 & 0.10 \\
\hline Manitoba & Delta, Hobson & 50.3 & -98.4 & 530 & 1999 & -0.031 & 0.165 & -0.2 & 0.86 \\
\hline Saskatchewan & St. Denis, Clark & 52.2 & -106.1 & 2753 & 1990 & 0.028 & 0.036 & 0.8 & 0.45 \\
\hline California & Lee Vining, Truan/Walsh & 38.5 & -121.7 & 1821 & 2000 & 0.212 & 0.042 & 5.0 & 0.002 \\
\hline British Columbia & Prince George, Dawson & 52.0 & -123.0 & 2601 & 2001 & 0.141 & 0.034 & 4.2 & 0.006 \\
\hline Alaska & Fairbanks, Rose & 61.4 & -143.3 & 1137 & 1991 & -0.018 & 0.008 & -2.3 & 0.04 \\
\hline
\end{tabular}

Missing years of data (Fig. 1): 2 for Ontario-Long Point, 3 for Manitoba, 3 for Alaska.

latitude) and distance west (hereafter, West) from the center of our study area $\left(93.6^{\circ} \mathrm{W}\right.$ longitude; data from Veness 2011$)$ as simultaneous explanatory variables. We also ran analyses where we either included or excluded sites where occupancy rates approached $100 \%$ on a regular basis because these sites (Saskatchewan, Manitoba, and Wisconsin) may have had surplus populations of Tree Swallows (i.e., more pairs than nest boxes) that might have prevented us from detecting actual population trends. In these analyses, we weighted sites by $1 /$ $\mathrm{SE}^{2}$ (a measure of precision) of their slope estimates (Steel and Torrie 1980).

We tested whether continental trend estimates were similar for BBS and box occupancy data. We used results of hierarchical analyses obtained from the BBS website (Sauer et al. 2011) to compare with our box occupancy data. Sauer et al. (2011) describe assumptions and pitfalls inherent in these analyses. We restricted this comparison to the interval for which we had data from at least 10 sites (starting in 1999) so that we covered a relatively broad geographic area. To create an index of box occupancy rates that weighted all sites equally, we first computed within each site the ratio between occupancy rate for each year (1999-2009) and average occupancy rate for all years in that interval to obtain a relative occupancy rate (e.g., if occupancy rate in 1999 was 0.75 and average occupancy from all years was 0.50 , relative occupancy for that year for that site would be 1.50). We then averaged relative occupancy rates for all sites within a year to create an annual occupancy index.

\section{RESULTS}

Ten of 16 sites had significant increases or decreases in box occupancy rates (Fig. 1, Table 1). All six sites east of $-78^{\circ} \mathrm{W}$ longitude had decreased occupancy ( 5 of these significantly so), whereas only two of ten sites west of $-78^{\circ} \mathrm{W}$ longitude had decreased occupancy. Both North $\left(F_{1,13}=10.9, P=0.006\right)$ and West $\left(F_{1,13}=11.2, P=0.005\right)$ were significant predictors of trend slopes (overall model $R^{2}=0.47, F_{2,13}=5.7, P=0.02$ ). If the Saskatchewan, Manitoba, and Wisconsin sites were excluded because they regularly had $\sim 100 \%$ occupancy, North $\left(F_{1,10}=8.4, P=0.02\right)$ and West $\left(F_{1,10}=8.6, P=0.01\right)$ still remained significant predictors of trend slopes (overall model $R^{2}=0.47, F_{2,10}=4.4, P=0.04$ ).

We reanalyzed data from Manitoba after excluding 2005, a year that followed two consecutive years of $100 \%$ predation by short-tailed weasels (Mustela erminea) (Fig. 1); this did not produce a significant trend for this site $(\beta=0.041 \pm 0.125$, $t=0.3, P=0.75$ ). Excluding 2008 from the Michigan data following a year of complete predation by cats (Felis domesticus) and raccoons (Procyon lotor; Fig. 1) resulted in a statistically significant positive trend for this site $(\beta=0.095$ 
$\pm 0.033,, t=2.9, P=0.01)$. Using the revised slopes from these grids did not affect the significant associations of trend slopes with North $\left(F_{1,13}=17.4, P=0.001\right)$ and West $\left(F_{1,13}=\right.$ 2.33, $P=0.0003$; overall model $R^{2}=0.67, F_{2,13}=13.0, P=$ 0.0008).

Trends for several sites were better modeled when polynomial terms were included (Fig. 1, especially the Ontario-Kingston site), but because of comparatively short monitoring intervals, there was insufficient statistical power for inclusion of cubic terms for most sites. Regardless, the linear term (year) remained in all final models, so that increases or decreases were not better revealed by inclusion of polynomial terms.

Our box occupancy indices between 1999 and 2009 were not significantly related to continental BBS indices $(r=0.17, P$ $=0.63$, Fig. 2). If we restricted comparison to the Eastern BBS area where Nebel et al. (2011) reported the strongest negative trends, and to our six sites east of $-78^{\circ} \mathrm{W}$ longitude, the two indices were still not significantly correlated over this interval $(r=-0.35, P=0.29$ ), but power of this analysis was low.

Fig. 2. Survey-wide annual Breeding Bird Survey indices (Sauer et al. 2011) of Tree Swallow populations and corresponding box occupancy indices (combined for all sites) between 1999 and 2009 (Fig. 1). Individual year data points are identified.

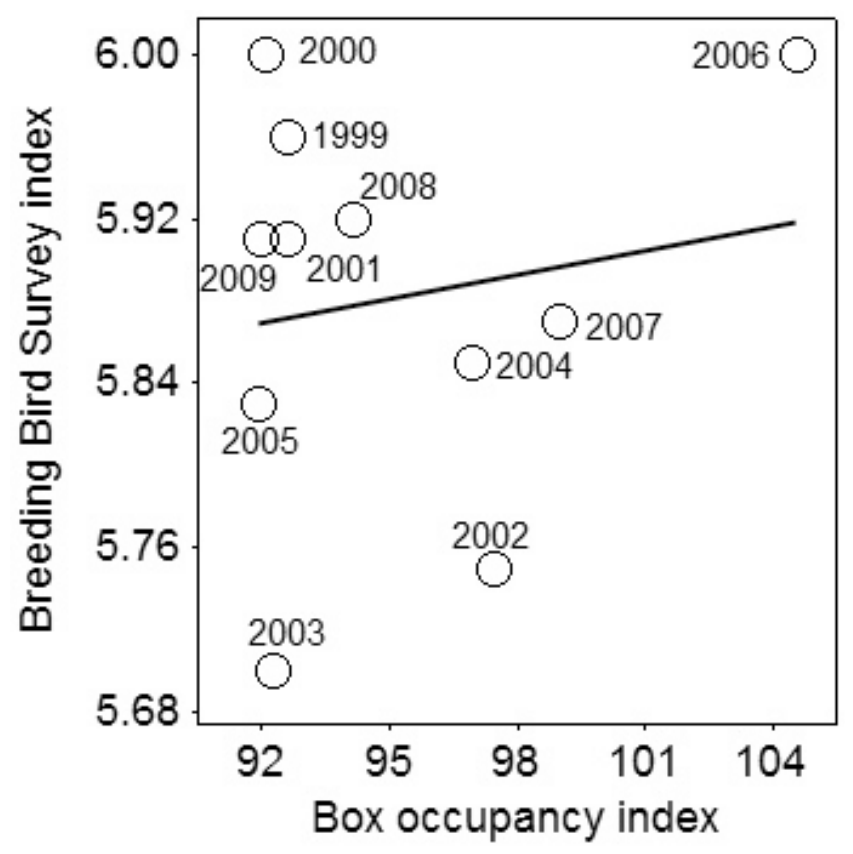

\section{DISCUSSION}

Our results revealed that, across North America, Tree Swallows at five of six (86\%) sites east of $-78^{\circ} \mathrm{W}$ longitude had significantly decreasing nest box occupancy rates, whereas four (five if an anomalous year is excluded) of ten (40 or $50 \%$ ) sites west of $-78^{\circ} \mathrm{W}$ longitude had significantly increasing occupancy rates. One western site had a significant decreasing trend. That this many sites had significant changes in box occupancy highlights the important of identifying potential causes for such definitive and geographically associated changes in nest box occupancy rates. Although the significantly negative trend observed for the data from the Alaska site appears to present a potential geographic anomaly when compared to most other western sites, further analysis may reveal common causation with eastern sites, or unique causation specific to the Alaska region.

Although we observed significant temporal trends in nest box occupancy rates of Tree Swallows, we are unable to determine from these data whether this translates into changes in the total number of Tree Swallows across their range. Analyses of data from Sauer et al. (2011) suggest continental decreases have occurred since 1966, but for the most part those decreases stopped in the early 1990s. Because it is tied to the road network, data collection by BBS tends to be biased towards areas with higher human population densities (Keller and Scallan 1999), but our sample of nest box sites is similarly not comprehensive in habitat or geographic scope. Whether higher human population densities are associated with increases in access to artificial nesting structures or overall decreases in quality of habitat is not known. On the other hand, we need to acknowledge that the interval considered (Hussell et al. 1992, Freed and Cann 2010, Nebel et al. 2011) can dramatically affect whether increasing or decreasing trends are observed; we had one site (Ontario-Kingston; possibly two if we include New Brunswick data from the 1940s) that has been monitored long enough to show both increases and decreases in occupancy rates. Thus, although short-term trends in Tree Swallow populations and other aerial insectivores may not reflect long-term trends, we need to remain vigilant.

We had insufficient time intervals and geographic coverage to robustly evaluate whether BBS and box occupancy trends were strongly related. However, our preliminary analyses suggested they were not. This is partly because we could not easily relate our spatial coverage to areas delineated by the BBS. With respect to making these comparisons in the first place, one may question whether changes in box occupancy rates are a valid source from which to draw inferences about population trends. In particular, many populations of birds have a contingent of breeding age individuals that are thwarted from breeding by a shortage of resources, particularly territories. In many species, these individuals become floaters (i.e., presumed to roam in search of vacant territories) that tend 
to be behaviorally cryptic (Smith 1978, Stutchbury and Robertson 1985, Shutler and Weatherhead 1991, 1992, 1994). There is some evidence that a proportion of floater Tree Swallows breed, but not to the same extent as regular box occupants (Lombardo 1988, Lifjeld et al. 1993, Kempenaers et al. 2001, Shutler and Clark 2003). Regardless, if floater populations are substantial, significant fluctuations in population trends may go undetected by analyzing box occupancy rates. However, this is likely a problem only where occupancy approaches $100 \%$, because given the opportunity, floaters of many species readily attempt to breed when territory owners are experimentally removed (e.g., Stewart and Aldrich 1951, Brown 1969, Robertson and Stutchbury 1988). Thus, high proportions of empty boxes are likely robust indicators of an absence or low density of floaters, and most of our sites where we were able to detect statistically significant trends had occupancy rates well below 100\%. One could also argue that data from nest boxes may not reflect trends of populations nesting in natural cavities. However, many aspects of Tree Swallow breeding do not differ substantially between natural cavities in trees and nest-boxes (Erskine and McLaren 1976, Robertson and Rendell 1990, Barber et al. 1996, Conrad et al. 2001). In addition, some of the preceding studies found that nest boxes appear to be preferred to natural cavities, so that if boxes are not limited, box occupancy rates should reflect overall population trends. Moreover, our nest box evidence for declines of Tree Swallows in the northeast is consistent with that of Nebel et al. (2011) from BBS data. Thus, it is reasonable to conclude that our results accurately reflect significant shifts in occupancy rates for Tree Swallows at nest boxes, and therefore in patterns of population density among sites.

One potential explanation for our results could be the result of breeding dispersal (movements between successive breeding sites) or natal dispersal (movement between site of birth and site of first breeding; sensu Greenwood and Harvey 1982) from sites with decreasing to increasing occupancy. However, this is unlikely given the breeding and natal dispersal distances for Tree Swallows (Shutler and Clark 2003, Winkler et al. 2004, 2005) and most other species of birds. Thus typical source-sink dynamics (Pulliam 1988) would not be expected to affect occupancy rates over the geographic scale reported here over the time frame involved. So, if region- or site-specific trends were not being driven by source-sink dynamics at a continental scale, some combination of differences in reproductive success rates, adult survival, and recruitment rates likely account for changes in box occupancy rates (i.e., sources feed themselves, sinks continue to sink and do not draw appreciably from other sources). Given that outcomes were common across broad geographic areas, plausible causes are likely occurring on a continental scale. Causation is not likely ascribable to genetic differences among our sites because Tree Swallows are panmictic, with the possible exception of California (Stenzel et al. 2009). Habitat loss in areas where birds winter, migrate, or breed could be spatially segregated and could produce the patterns we observed; for example, forest succession in the east may be reducing open habitats preferred by Tree Swallows. However, habitat has remained unchanged over a 70 -year period at the site with the steepest and most significant decline (New Brunswick). Disease prevalence and virulence can also vary geographically (e.g., Desser et al. 1978, Weatherhead et al. 1991, Shutler et al. 1995), but it would be exceedingly difficult to evaluate this possibility, especially retroactively. One simple explanation may be from effects of gradual climate change in breeding, migrating, or wintering areas (Dunn and Winkler 1999, but see Hussell 2003b). If so, it is not clear whether its influence is on insect phenology or productivity, energy budgets of Tree Swallows (Dawson et al. 2005), disease virulence and prevalence, or agricultural or forestry practices that in turn may have impacts on insects or on the birds themselves (Ghilain and Bélisle 2008). Another possibility is that bedrock in the northeast has not recovered from prolonged acid precipitation, leading to reduced calcium availability for both insects and birds (Graveland et al. 1994, Bidwell and Dawson 2005, Dawson and Bidwell 2005, Pabian and Brittingham 2011). This in turn could affect birds' ability to produce eggs and rear offspring with high survival prospects. It is not clear why any of these explanations would affect aerial more than other avian insectivores (Nebel et al. 2011), or why the opposite population trends would occur in the southwest.

The broad suite of declining insectivores identified by Nebel et al. (2011) raises questions about the fate of other aerial insectivores such as damselflies, dragonflies, and bats. Unfortunately, we are not aware of coordinated continental monitoring programs for insect or bat population trends. However, it is noteworthy that one hypothesis for white-nose syndrome in bats is that they have insufficient fat reserves during winter to combat infections, including those from the fungus that produces the telltale signs. A paucity of insects in advance of hibernation could lead to lower than average fat reserves. Recent evidence, however, does not support this hypothesis (Lorch et al. 2011). Nebel et al. (2011) also noted that long-distance migrants appear to be most affected, implying that events farther south may be the place to begin looking for explanations. However, Tree Swallows and several other species evaluated by Nebel et al. (2011) are relatively short-distance migrants, particularly in the southern part of their range, so at least some of the population changes seen in these species are likely attributable to changes in the vicinity of breeding areas. Moreover, the diverse assemblage of birds identified by the analyses of Nebel et al. (2011) possess few commonalities in terms of wintering locations, migratory 
routes, or timing. Our results indicate that populations of Tree Swallows bear close monitoring; they may provide keys to identifying many of the unknowns contributing to changes in populations of other species of aerial insectivores.

Responses to this article can be read online at: http://www.ace-eco.org/vol7/iss 1/art3/responses/

\section{Acknowledgments:}

With exception of the first author, author order was determined by the number of box-years contributed to the dataset. We thank Phil Taylor for suggesting this endeavor and various forms of assistance, Megan Colwell, Holly Lightfoot, and Adele Mullie for feedback, legions of students and colleagues who have helped us collect these data, and two reviewers for extraordinarily thorough comments. We acknowledge the enormous effort of volunteers and government agencies in providing BBS data and access to it. Funding sources included NSF (in Ithaca by NSF grants IBN-013437, IBN-920723, IBN-0131437, DEB-0717021 to D. W. Winkler, and IOS-0744753 to Winkler and C. Vleck) and NSERC. The Ontario-Long Point site was funded continuously since its inception by Long Point Bird Observatory (a program of Bird Studies Canada after 1997). For the sake of brevity, we refer readers to our other Tree Swallow publications for acknowledgments of research assistants and additional funding sources.

\section{LITERATURE CITED}

Askins, R. A. 1995. Hostile landscapes and the decline of migratory songbirds. Science 267:1956-195.

Barber, C. A., R. J. Robertson, and P. T. Boag. 1996. The high frequency of extra-pair paternity in Tree Swallows is not an artifact of nest boxes. Behavioral Ecology and Sociobiology 38:425-430. http://dx.doi.org/10.1007/s002650 $\underline{050260}$

Bidwell, M. T., and R. D. Dawson. 2005. Calcium availability limits reproductive output of Tree Swallows (Tachycineta bicolor) in a nonacidified landscape. Auk 122:246-254. http: //dx.doi.org/10.1642/0004-8038(2005)122[0246:CALROO] 2.0.CO;2

Böhning-Gaese, K., M. L. Taper, and J. H. Brown. 1993. Are declines in North American insectivorous songbirds due to causes on the breeding range? Conservation Biology 7:76-86. http://dx.doi.org/10.1046/j.1523-1739.1993.07010076.x

Brown, J. L. 1969. Territorial behavior and population regulation in birds: a review and re-evaluation. Wilson Bulletin 81:293-329.
Chapman, L. B. 1935. Studies of a Tree Swallow colony. Bird Banding 6:45-57. http://dx.doi.org/10.2307/4509338

Conrad, K. F., P. V. Johnston, C. Crossman, B. Kempenaers, R. J. Robertson, N. T. Wheelwright, and P. T. Boag. 2001. High levels of extrapair paternity in an isolated, low-density, island population of Tree Swallows (Tachycineta bicolor). Molecular Evolution 10:801-808.

Crawley, M. J. 2005. Statistics: An introduction using $R$. Wiley, West Sussex, England. http://dx.doi.org/10.1002/9781 119941750

Dawson R. D., and M. T. Bidwell. 2005. Dietary calcium limits size and growth of nestling Tree Swallows in a non-acidified landscape. Journal of Avian Biology 36:127-134. http://dx.doi. org/10.1111/j.0908-8857.2005.03406.X

Dawson R. D., C. C. Lawrie, and E. L. O'Brien. 2005. The importance of microclimate variation in determining size, growth and survival of offspring: experimental evidence from a cavity nesting passerine. Oecologia 144:499-507. http://dx. doi.org/10.1007/s00442-005-0075-7

Desser, S. S., J. Stuht, and A. M. Fallis. 1978. Leucocytozoonosis in Canada geese in upper Michigan I. Strain differences among geese from different localities. Journal of Wildlife Diseases 14:124-131.

Dunn, P. O. and D. W. Winkler. 1999. Climate change has affected breeding date of Tree Swallows throughout North America. Proceedings of the Royal Society of London, Series B 266:2487-2490. http://dx.doi.org/10.1098/rspb.1999.0950

Erskine, A. J., and W. D. McLaren. 1976. Comparative nesting biology of some hole-nesting birds in the Cariboo Parklands, British Columbia. Wilson Bulletin 88:611-620.

Freed, L. A., and R. L. Cann. 2010. Misleading trend analysis and decline of Hawaiian forest birds. Condor 112:213-221. http://dx.doi.org/10.1525/cond.2010.090092

Ghilain, A., and M. Bélisle. 2008. Breeding success of Tree Swallows along a gradient of agricultural intensification. Ecological Applications 18:1140-1154. http://dx.doi.org/10.1 $\underline{890 / 07-1107.1}$

Golondrinas. 2011. Golondrinas de las Americas. http:// golondrinas.cornell.edu/.

Graveland, J. R., R. van der Wal, J. H. van Balen, and A. J. van Noordwijk. 1994. Poor reproduction in forest passerines from decline of snail abundance on acidified soils. Nature 368:446-448. http://dx.doi.org/10.1038/368446a0

Greenwood, P. J., and P. H. Harvey. 1982. The natal and breeding dispersal of birds. Annual Review of Ecology and 
Systematics 13:1-21. http://dx.doi.org/10.1146/annurev.es.1 3.110182.000245

Hussell, D. J. T. 1983. Tree Swallows raise two broods in a season. Wilson Bulletin 95: 470-471.

Hussell, D. J. T. 2003a. Two more double-brooded Tree Swallows. North American Bird Bander 28: 49-51.

Hussell, D. J. T. 2003b. Climate change, spring temperatures, and timing of breeding of Tree Swallows (Tachycineta bicolor) in southern Ontario. Auk 120:607-618. http://dx.doi. org/10.1642/0004-8038(2003)120[0607:CCSTAT]2.0.CO;2

Hussell, D. J. T. 2012. The influence of food abundance on nest box occupancy and territory size in the Tree Swallow, a species that does not defend a feeding territory. Condor in press.

Hussell, D. J. T., M. H. Mather, and P. H. Sinclair. 1992. Trends in numbers of tropical and temperate-wintering migrant landbirds at Long Point, Ontario, 1961-1988. Pages 101-114 in Ecology and conservation of neotropical migrant landbirds (J. M. Hagan III and D. W. Johnston, Eds.). Smithsonian Inst., Washington, D. C., U.S.A.

Hussell, D. J. T., and T. E. Quinney. 1987. Food abundance and clutch size of Tree Swallows Tachycineta bicolor. Ibis 129:243-258. http://dx.doi.org/10.1111/j.1474-919X.1987.tb03204. $\underline{\mathrm{X}}$

Jones, J. 2003. Tree Swallows (Tachycineta bicolor): A new model organism? Auk 120:591-599. http://dx.doi.org/10.164 2/0004-8038(2003)120[0591:TSTBAN]2.0.CO;2

Keller, C. M. E., and J. T. Scallan. 1999. Potential roadside biases due to habitat changes along Breeding Bird Survey routes. Condor 101:50-57. http://dx.doi.org/10.2307/1370445

Kempenaers, B., S. Everding, C. Bishop, P. Boag, and R. J. Robertson. 2001. Extra-pair paternity and the reproductive role of male floaters in the Tree Swallow (Tachycineta bicolor). Behavioral Ecology and Sociobiology 49:251-259 http://dx.doi.org/10.1007/s002650000305

Lifjeld, J. T., P. O. Dunn, R. J. Robertson, and P. T. Boag. 1993. Extra-pair paternity in monogamous Tree Swallows. Animal Behaviour 45:213-229. http://dx.doi.org/10.1006/an be.1993.1028

Lombardo, M. P. 1988. Evidence of intraspecific brood parasitism in the Tree Swallow. Wilson Bulletin 100:126128.

Lorch, J. M., C. U. Meteyer, M. J. Behr, J. G. Boyles, P. M. Cryan, A. C. Hicks, A. E. Ballmann, J. T. H. Coleman, D. N. Redell, D. M. Reeder, and D. S. Blehert. 2011. Experimental infection of bats with Geomyces destructans causes whitenose syndrome. Nature 480:376-378. http://dx.doi.org/10.1038/ $\underline{\text { nature } 10590}$

Monroe, A. P., K. K. Hallinger, R. L. Brasso, and D. A. Cristol. 2008. Occurrence and implications of double brooding in a southern population of Tree Swallows. Condor 110:382-386. http://dx.doi.org/10.1525/cond.2008.8341

Muldal, A., H. L. Gibbs, and R. J. Robertson. 1985. Preferred nest spacing of an obligate cavity-nesting bird, the Tree Swallow. Condor 87:356-363. http://dx.doi.org/10.2307/1367216

Nebel, S., A. Mills, J. D. McCracken, and P. D. Taylor. 2011. Declines of aerial insectivores in North America follow a geographic gradient. Conservation and Ecology - Écologie et conservation des oiseaux 5(2):1. [online] URL: http://www. ace-eco.org/vol5/iss2/art1/.

Pabian, S. E., and M. C. Brittingham. 2011. Soil calcium availability limits forest songbird productivity and density. Auk 128:441-447. http://dx.doi.org/10.1525/auk.2011.10283

Paynter, R. A. 1954. Interrelations between clutch-size, broodsize, prefledging survival, and weight in Kent Island Tree Swallows. Bird Banding 25: 35-38, 102-110, 136-148.

Pulliam, H. R. 1988. Sources, sinks, and population regulation. American Naturalist 132:652-661. http://dx.doi.org/10.1086/ $\underline{284880}$

R Core Development Team. 2006. R: A language and environment for statistical computing. $\mathrm{R}$ Foundation for Statistical Computing, Vienna, Austria.

Robbins, C. S., J. R. Sauer, R. S. Greenberg, and S. Droege. 1989. Population declines in North American birds that migrate to the neotropics. Proceedings of the National Academy of Science (U.S.A.) 86:7658-7662. http://dx.doi.org /10.1073/pnas.86.19.7658

Robertson, R. J., and W. B. Rendell. 1990. A comparison of the breeding ecology of a secondary cavity nesting bird, the Tree Swallow (Tachycineta bicolor), breeding in nest-boxes and natural cavities. Canadian Journal of Zoology 68:10461052. http://dx.doi.org/10.1139/z90-152

Robertson, R. J., and B. J. Stutchbury. 1988. Experimental evidence for sexually selected infanticide in Tree Swallows. Animal Behaviour 36:749-753 http://dx.doi.org/10.1016/S000 3-3472(88)80158-1

Sauer, J. R., J. E. Hines, J. E. Fallon, K. L. Pardieck, D. J. Ziolkowski, Jr., and W. A. Link. 2011. The North American Breeding Bird Survey, Results and Analysis 1966 - 2009. Version 3.23.2011. U.S.G.S. Patuxent Wildlife Research 
Center, Laurel, MD. http://www.mbr-pwrc.usgs.gov/bbs/ trend/tf09.html

Shutler, D., G. F. Bennett, and A. Mullie. 1995. Sex proportions of Haemoproteus blood parasites and local mate competition. Proceedings of the National Academy of Sciences (USA) 92:6748-6752. http://dx.doi.org/10.1073/pna s.92.15.6748

Shutler, D., and R. G. Clark. 2003. Causes and consequences of Tree Swallow (Tachycineta bicolor) dispersal. Auk 120:619-631. http://dx.doi.org/10.1642/0004-8038(2003)120 [0619:CACOTS]2.0.CO;2

Shutler, D., R. G. Clark, C. Fehr, and A. W. Diamond. 2006. Time and recruitment costs as currencies in manipulation studies on the costs of reproduction. Ecology 87:2938-2946. http://dx.doi.org/10.1890/0012-9658(2006)87[2938:TARCAC] 2.0.CO;2

Shutler, D., and P. J. Weatherhead. 1991. Owner and floater red-winged blackbirds: determinants of status. Behavioral Ecology and Sociobiology 28:235-241. http://dx.doi.org/10.1 $\underline{\text { 007/BF00175095 }}$

Shutler, D., and P. J. Weatherhead. 1992. Surplus territory contenders in the red-winged blackbird: where are the desperados? Behavioral Ecology and Sociobiology 31:97-106. http://dx.doi.org/10.1007/BF00166342

Shutler, D., and P. J. Weatherhead. 1994. Movement patterns and territory acquisition by floater red-winged blackbirds. Canadian Journal of Zoology 72:712-720. http://dx.doi.org/ $\underline{10.1139 / \mathrm{z} 94-096}$

Smith, S. M. 1978. The "underworld" in a territorial sparrow: adaptive strategy for floaters. American Naturalist 112:57 1-582. http://dx.doi.org/10.1086/283298

Steel, R. G. D., and J. H. Torrie. 1980. Principles and procedures of statistics: A biometrical approach. McGrawHill, Toronto.

Stenzler, L. M., C. A. Makarewich, A. Coulon, D. R. Ardia, I. J. Lovette, and D. W. Winkler. 2009. Subtle edge-of-range genetic structuring in transcontinentally distributed North American Tree Swallows. Condor 111:470-478. http://dx.doi. org/10.1525/cond.2009.080052

Stewart, R. E., and J. W. Aldrich. 1951. Removal and repopulation of breeding birds in a spruce-fir forest community. Auk 68:471-482.

Stutchbury, B. J., and R. J. Robertson. 1985. Floating populations of female Tree Swallows. Auk 102:651-654.

Veness, C. 2011. Convert between latitude/longitude \& OS National Grid Reference points. http://www.movable-type. co.uk/scripts/latlong-gridref.html
Weatherhead, P. J., G. F. Bennett, and D. Shutler. 1991. Sexual selection and parasites in wood-warblers. Auk 108:147-152.

Wasserman, J. 2003. Tree Swallows double-clutch in southern California. North American Bird Bander 28:121.

Winkler, D. W., K. Hallinger, D. R. Ardia, R. J. Robertson, B. J. Stutchbury and R. R. Cohen. 2011. Tree Swallow (Tachycineta bicolor), The Birds of North America Online (A. Poole, Ed.). Ithaca: Cornell Lab of Ornithology; Retrieved from the Birds of North America Online: http://bna.birds. cornell.edu.bnaproxy.birds.cornell.edu/bna/species/011

Winkler, D. W., P. H. Wrege, P. E. Allen, T. L. Kast, P. Senesac, M. F. Wasson, P. E. Llambías, V. Ferretti, and P. J. Sullivan. 2004. Breeding dispersal and philopatry in the Tree Swallow. Condor 106:768-776. http://dx.doi.org/10.1650/7634

Winkler, D. W., P. H. Wrege, P. E. Allen, T. L. Kast, P. Senesac, M. F. Wasson, and P. J. Sullivan. 2005. The natal dispersal of Tree Swallows in a continuous mainland environment. Journal of Animal Ecology 74:1080-1090. http ://dx.doi.org/10.1111/j.1365-2656.2005.01007.x 